\title{
The Relationship Between Work-Life Balance Initiatives and Organizational Citizenship Behavior: The Mediating Role of Perceived Organizational Support
}

\author{
Khurram Shakir ${ }^{1}$ \\ Siraj Jamal Siddiqui ${ }^{2}$
}

\begin{abstract}
Work-Life initiatives refer to the organizational policies that helps an employee to create balance between his/her professional and personal life, whereas organizational citizenship behavior $(O C B)$ refers to the voluntary behavior on part of the employee taking on additional responsibilities apart from their usual job descriptions developing a sense of ownership towards their workplace. The primal objective of this study is to explore whether work-life balance initiatives in any way influence organizational citizenship behavior and employees' perception of such initiatives taken by their organizations and if such measures create a sense among workers to go beyond their duties at work. The purpose of this study is to test causal relationship among the studied variable. The primary data from 540 sample size selected through convenience sampling by using survey questionnaire from a number of banking and telecom companies of Pakistan. The data was analyzed through confirmatory factor analysis (CFA) technique and path analysis. The outcomes of the study show that relationship between Work-Life Balance (WLB) and Organization Citizenship Behavior (OCB) is fully mediated by Perceived Organizational Support (POS) which also highlighted the crucial role of Perceived Organizational Support (POS). The results of the study indicate that work-life balance practices have no direct effect on organizational citizenship behavior, while perceived organizational support shows full mediation between WLB and OCB and this suggest to the Work-Life Balance (WLB) practitioners that providing work-life balance options are not enough to get desirable results but the fairness and availability of such options across the organization are mandatory to achieve Organization Citizenship Behaviour (OCB).
\end{abstract}

JEL Classification: M50, M51, M52, M53, M54

Keywords: Work-life Balance, Perceived Organizational Support, Organization Citizenship Behavior

\section{INTRODUCTION}

Work-Life Balance and Organization Citizenship Behavior are phenomena that have been subjects of constant research amongst organization behavior theorists since 1970's. The paradigm shift in the economy has made it clear to the organizations that the only way to compete and survive in this global market is their human resource, as all the efforts to gain competitive edge are dependent on their performance and productivity. Organ (2018), corroborates that scholarship in the area of OCB has enriched significantly in the last 20 years, expanding its associations to culture, attitudes, personality, mood state, stress, and organizational performance.

1- IQRA University, Karachi, Pakistan Email: khurramshakir@yahoo.com 2- IQRA University, Karachi, Pakistan

\begin{tabular}{lll}
\hline JISR-MSSE & Volume 16 & Number 2 \\
6
\end{tabular}


Zare, H., Haghgooyan, Z., \& Karimi Asl, Z. (2014), explicate that in recent times, a great number of management researches consider the development of human resources and betterment of quality of work life as the primal indicators of the functional sustainability of the organizations. Oparanma \& Nwaeke (2015), advocates that the comprehensive human resource management practices provide the main foundations for business competitive edge. Shaukat, Ashraf \& Ghafoor (2015), argue that employee performance ultimately guarantees either the success or failure of the organizations. Companies assuming high success levels have reached a realization that one of the primal factors influencing organizational performance is nonetheless its human resource.

Now organizations consider employees' recruitment, their retention and engagement with organization as their first priority amongst all competitive strategies available to them across the world, as indicated by Konrad \& Mangel, (2000). The globalization has made employers to seek employees to work exceptionally not only in their domains but also beyond their job descriptions. As stated by Garg \& Rastogi (2006), that firms have comprehended that their survival in this challenging situation of business globalization is not possible without organization citizenship behavior. Oktariani, D., Hubeis, A.V. S., \& Sukandar, D. (2017), have also established that within the limited availability conditions, human resource management has become essential, allowing the corporate organizations to register the sustainability of workforce in fulfilling in an efficient working condition.

On the other hand, Skinner, Pocock \& Williams (2008), are of the view that Work-life balance has emerged as a vital human resource management issue due to varying arrangements of labor market. A shift in employees' demand at work has been noticed in recent decades and emerging diversity in workforce demands different work settings and policies at work, as their working priorities have been changed and most of the employees are striving for a balance between their work and family life. Oludayo, O. A., Falola, H. O., Obianuju, A., \& Demilade, F. (2018), express a substantial responsibility lies on the managers of organizations, particularly in the banking sector, to generate different ways to create a balance in the priorities of their employees.

Ramachandra \& Suman, (2007) stated that employees are facing challenges across the world to figure out a way they can manage their work and family life in equilibrium. Jahanian, A., Nawaz, N., Yamin, R., \& Nawaz, M. A. (2012), complemented this by arguing that such challenges are making employees exasperated and creating hindrance for them in rendering prime performance. Employers and organizations are taking drastic steps to respond to such demands from employees and introduce policies and procedures which help employees to balance their work and family life, simultaneously bringing their performance and productivity back on track.

Pakistan as a developing country is faced with challenges of performance and productivity in its organizations to compete globally despite introducing different HR initiatives at organizational level; as Khilji (2003), identified a gap between practices and implementation of human resource management in Pakistan along with issues of power distance, elitism and approach of dependence in HRM. However, Qayum (2011), pointed out that human resource management is considerably a new field in Pakistan but has developed significantly in the last ten years and Muhammad, Nadeem, and Ashfaq, (2011), corroborates this notion by highlighting that comparatively in most private organizations HR has become a vital part of

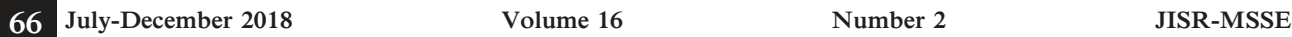


organizations' overall strategy to meet the global standards of business process.

Majority of organizations in Pakistan are striving to drive that extra role behavior in their employees which push them to go beyond their responsibilities and bring out of the box solutions for the excellence of the organization. Such desired behavior is only possible when these organizational initiatives will be perceived supportive by employees so they will feel a sense of ownership and go beyond their boundaries for the betterment of the organization. Baran et al. (2012) in their research comprehensively scrutinized the variables related to perceived organizational support and were able to deduce that the Perceived Organizational Support is generally elevated when employees prevail a sense that the projected organizational change would be beneficial for their personal and professional well-being.

Motowidlo (2003), identified that the deficiency of organizational citizenship behavior may possibly generate undesirable consequences like poor performance and enhanced turnover rate. However; there is a possibility that the initiatives of work-life balance may impact organizational citizen behavior (OCB) at the workplace. Oludayo, O. A., et.al. (2018), noted that various work-life balance initiatives as being practiced in banks may not always be successful in catering exclusive needs of some employees and so it is desirable that management must figure out different methods to attend to these needs as there is no general rule. According to Konrad \&Mangle (2000), the organization's efforts for improving the staffs' work-life quality, might be compensated by great voluntary efforts by staffs. Rondeau \& Lemelin (1998), stated that the provision of work-family policies as an HR practice has been acknowledged as showing a positive link with OCB.

To conclude, it can be said with conviction that improved OCB leads to creative work, out of the box thinking, performance enhancement and increased confidence levels on the part of the employees, while high-end productivity is guaranteed on part of the organization. The present study probes organization's efforts related to employees work-life balance, particularly in relation with the banking and telecom sectors and to find out if such initiatives on organization's part result in employees' organizational citizenship behavior. It will also be interesting to note how employees perceive such policies and whether such policies create a sense among workers to go beyond their duties at work.

Even though OCB has been the subject of study of many pieces of research in the past such as Beauregard \& Henry (2009); Butts, Casper, \& Yang (2013) and Muse \& Pichler, (2011), conclude that the impact of work-life balance initiatives on OCB has not much been observed; even particularly in the telecom and banking sectors respectively (Oludayo, O. A.et.al, 2018). The main motivation behind this research is to gain a broader and profound understanding of OCB mediated by the organizational support perception created through work-life balance initiatives. Moreover, the scope of research on OCB also needs to be spread among Muslim majority countries and organizations as expressed by Kamil, N. M., Sulaimam, M., Selladurai, S., \& Khalid, N. (2015). Likewise, this study will give an insight to researchers in Pakistan to further explore the missing links towards OCB within the organizations and it would be a great help for those employers who are currently executing work-life balance practices at their workplace and want to explore more about such practices in relation with OCB. Furthermore, industries other than banking and telecommunication in Pakistan can use findings of this study to enhance their performance by achieving OCB. 


\section{LITERATURE REVIEW}

\section{Work-Life Balance (WLB)}

Sheikh, M. A., Ashiq, A., Mehar, M. R., Hasan, A., \& Khalid, M. (2018), refers to WLB as the maintenance of right balance between working hours, psychological \& emotional involvement in the work and family and satisfaction derived from the work and family roles on part of the employees. Osterman (1995), stated that work-life balance practices are those established operational and practical settings, as well as official and informal procedures, that support employees to effortlessly cope the conflicting domains of work and personal lives. Butts et al., (2013), proposed that the practice of work-life balance measures should bring an optimistic outlook and conducts amongst workers due to the direct advantage received from the policies availed. Policies of work-life balance aid workers in dealing with their personal and family life in an improved manner, providing a boost to their behaviors and attitudes like organizational affection, as suggested by Groover \& Croocker, (1995). Kuusisto (2017), furthers the argument that suitably utilized investments upon the wellbeing of employees are likely to result in gainful returns in the in the long run. Moreover, Harrell-Cook, G., Levitt, K., \& Grimm, J. (2017) maintain that healthy and rewarding living standards can be preserved through WLB, that will ultimately result in better performance levels on part of the employees.

On the contrary, Hughes \& Bozionelos, (2007) evidently linked issues in the work-life balance of employees with employee withdrawal behavior as well as turnover and bogus sick absences. Guest (2002), stated that the firm's cultural support, which is acknowledged as the implied support, is more substantial in defining the observed level of work-life support than the support provided at the policy level. Yasbek (2004), enlightens that this give and take structure brings a boost in productivity at work, as employers facilitating employees in the manner of work-life balance initiatives at work is perceived as a favor and the workers squaring this favor by working with more vigor at work.

\section{Organizational Citizenship Behaviour (OCB)}

According to Bolino \& Turnly (2005), several workers who willingly undertake extra work for their firms and involve themselves in contributing towards effective operational tasking, not only perform better at their official duties, but also perform diligently by exhibiting responsibility at other non-traditional tasks as well, which are explained in OB theories as OCBs. Cichorzewska \& Rakowska (2017), comprehensively define OCB as the behaviors that are not confined within the bounds of an employment contract or job description and are also valuable contributions to the overall organizational proficiency.

The word OCB was introduced by Organ (1988). He defined OCB as an unrestricted attitude that goes a faraway than someones officially assigned a task and is planned to expedite other workers in the firms. As per MacKenzie, Podsakoff, \& Ahearne (1998), OCB is the flexible attitude on behalf of that worker that straightly effects on the functioning of a firm, irrespective of the worker's impartial output. Organ (1988), rationalized that when workers do their work in a situation that persuades satisfaction, they often sense through norm of reciprocity, subsequently in assisting and lending helpful attitudes that may originate OCB. According to Robbins, S. P., Judge, T. A. (2017), Organizational Citizenship Behavior (OCB) is
68 July-December 2018
Volume 16
Number 2
JISR-MSSE 
unrestricted behavior which is not part of an employee's official job requirements, and that contributes to the psychological and social environment of the workplace. Various relationships have been found with the previous practices such as POS, Eisenberger et. al. (1990); Moorman, Blakely \& Niehoff, (1998), and role efficacy, Daniel et. al. (2007).

\section{Perceived Organizational Support (POS)}

Erdogan \& Enders (2007), defined Perceived Organizational Support (POS) as the level to which an individual trust that the organization cares about him/her, values his/her input and provides his/her with assistance and support. The perceived organizational support concept was initiated by Eisenberger \& Rhoades (1986), in their work of organizational support theory (OST).

Eisenberger \& Stinglhamber (2011) suggested that OST hypothesizes, that an element of business achievement is the opinion levels of employees development regarding the organization's tendency towards employees' well-being, like the organization giving importance to employees' participation and showing concern about their welfare. As stated by Eisenberger et. al. (2002), that the way employee is handled by the organization, helps him/her to assess and develop organization's identification, as such that the perception which employee has about the organization is very significant for employee's wellbeing as well as for organization's achievements. It is claimed by social exchange philosophers that reception of enhanced practices of wellbeing may participate in additional organizational achievements. Precisely employees pay off their bosses with enhanced performance at work as established by Eisenberger et. al., (1986).

\section{The relationship between WLB, POS, and OCB}

Provision of work-life balance at work does have an impact on employee's views positively about the organization as it triggers a sense that organization does care about the employees. Zhong et. al. (2016), identified that the notion of employee wellbeing is recently being deliberated as benefits which are less tangible in nature and has commonly been observed an employee's perceived work setting, social situation in which typically the work is carried out and organizational provisions and care witnessed by employees. As Baral \& Bhargava (2010), pointed out that WLB has the ability to enhance and impact employee behavior and attitudes for the organization. If these work-life efforts are practiced and implemented properly they may bring POS. Krishnan \& Mary (2012), recognized work-family support as an originator of POS. O'Driscoll et. al. (2003), indicated that the association between workers' use of work-life balance advantages and work-to-life conflict was mediated by opinions about the organization as being supportive of other than work issues. Muse, Giles, and Field (2008) concluded that results of different researches validate that provision of WLB benefits are actually deliberated by workers, increases insights of organizational support \& organizational affective commitment $(\mathrm{OAC})$ and reciprocation in the terms of improved role, better task and linked performance.

As Crooker et. al. (2002), found that providing work-life policies only is not sufficient to bring balance for employees unless these policies are well communicated and open for access to all employees. So the availability of WLB policies is not the surety that workers will perceive them as supportive efforts from the organization, but fair implementation and access across the organization of such policies make employees think that organization cares for their

\begin{tabular}{lllll}
\hline JISR-MSSE & Volume 16 & Number 2 & July-December 2018 & 69
\end{tabular}


wellbeing. Employees sense themselves deeply motivated when the POS backs for WLB as established by Eaton, S.C. (2003).

Eisenberger et. al. (1986) and Cho \& Treadway (2010), proposed that when workers have desired support and resources from the organization, then spontaneously workers in the result of these favors will respond by commitment and citizenship behavior to the organization. Such responses from employees demonstrate how they perceive every effort of the organization in their support and how POS results in OCB. Eisenberger et. al., (1990) probed the association between POS and OCB and found a significant and positive association between both variables.

Muhammed (2014), suggested that the workers may trust offerings of valuable WLB benefits by the firms as a patronage given to the workers for their personal life and based on many practical pieces of evidence citing the connection among POS and OCB. Wayne et. al. (2002), endorsed that POS was associated with altruism and compliance dimensions of OCB. It is also established in their study that POS was incrementally and intensely related to OCB in comparison with affective commitment (AC). Findings of the study by Chen, Eisenberger, Johnson, Sucharski, \& Aselage (2009), propose that POS causes extra role conducts. Lambert (2000), examined the impact of perceived usefulness and real utilization of WLB advantages on individual OCB (e.g. possibility of being there a standard meeting or creating ideas.) It was recognized that giving officials extras control over the combination of work and life has the perspective to process losses and potential for optimistic social advantages that go far away from the instantaneous utilization of tractability.

From the literature review, following hypotheses have been set up:

H1: Work-life balance initiatives effects on perceived organizational support.

H2: Work-life balance affects organizational citizenship behavior.

H3: Perceived organizational support effects organizational citizenship behavior.

H4: Perceived organizational support mediates the relationship between WLB and OCB.

Figure A The hypothesized model

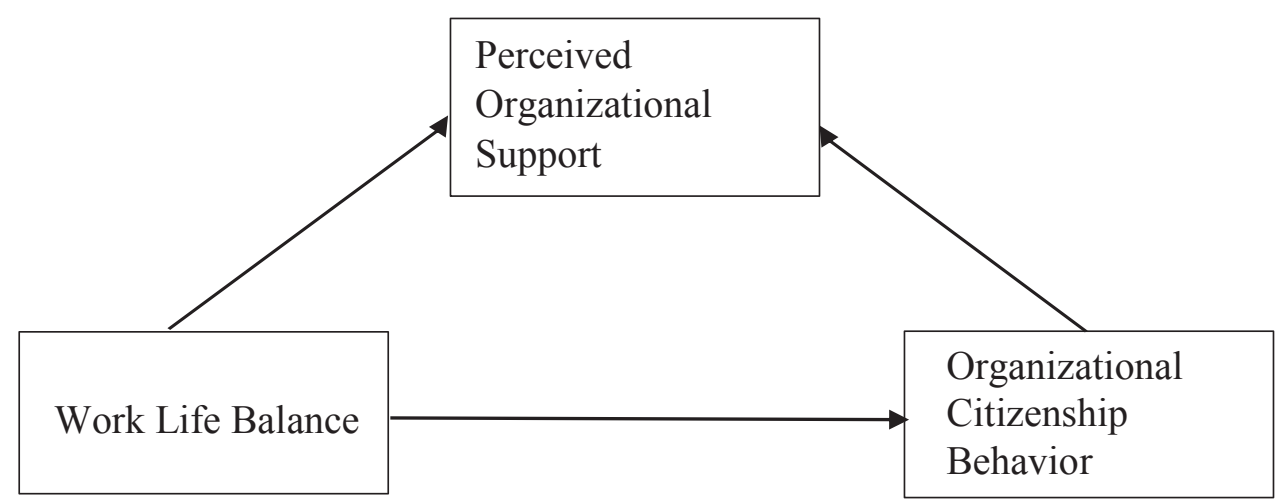




\section{METHODOLOGY}

\section{Sample and Data Collection}

This is a causal study where the effect of work-life balance, perceived organizational support and organizational citizenship behavior is evaluated on the grounds of participant's perception which they reported about the above-mentioned variables. The adopted sampling technique for this study is nonprobability convenience sampling technique. For measuring the viewpoint of participants in this research the best suitable research design, which is a survey, in this case, has been chosen which enables the researcher to collect data from a large number of population. Sekaran (2002), suggests that among others process of information selection, the surveys are the most dominant information collection process if the expert knows precisely what is requisite and how to assess the factors of concern.

The data collection is based on 540 respondents from service sector of the public and private banking and telecom companies of Pakistan as Leedy \& Ormrod (2001), suggest that heterogeneous populations require larger samples and homogeneous populations require smaller samples. All leading banks and telecom companies were approached comprising National Banks of Pakistan, MCB, Allied Bank, Habib Bank Ltd, Bank Alfalah, Faysal Bank, Soneri Bank, Bank Islami, Al Baraka, Bank Al Habib, PTCL, Mobilink, Ufone, Zong, Warid, and Telenor Pakistan.

\section{Measures}

A 21-item survey questionnaire is used here for the data collection and to test hypothesized model figure A. Sekaran (2002), recommends that the foremost procedure of information selection is the survey that is the most prevailing process if the expert exactly recognizes what is necessary and how to evaluate the aspects of concern. Entire items of the questionnaire used are evaluated on the 5-point rating scale (Likert scale) for the variables included in the model. The scale items of Work-life Balance (WLB), Perceived Organisational Support(POS) and Organisational Citizenship Behavior(OCB)had been adopted from the researchers, Paré, Tremblay \& Lalonde , Eisenberger, et. al., (1986), Lee \& Allen (2002), and Motowidlo \& Van Scotter (1994)

\section{Statistical Technique}

AMOS has been used for analyzing the data and model authentication and its reliability which also validates the relationship and strength of results. Moreover; SPSS 22 has also been used for validation of the instrument and confirming the respondent's profiles.

\section{Reliability}

For checking the reliability of the variables Cronbach's Alpha, Composite Reliability and Average Variance Extracted has been used in this study. As stated by Kumar (2005), that reliability is considered a level of uniformity and the degree of measurement in terms of its accuracy and predictability. Brakeman \& Gottman (1986), stated that Cronbach's Alpha values 0.7 or above are endorsed by experts in the field of research. Whereas $\mathrm{CR}$ values above 0.7 are recommended by Fornell \& Larcker, (1981). The below-mentioned table depicts that Cronbach's Alpha and CR values are above 0.7 and can be considered as acceptable for reliability. 


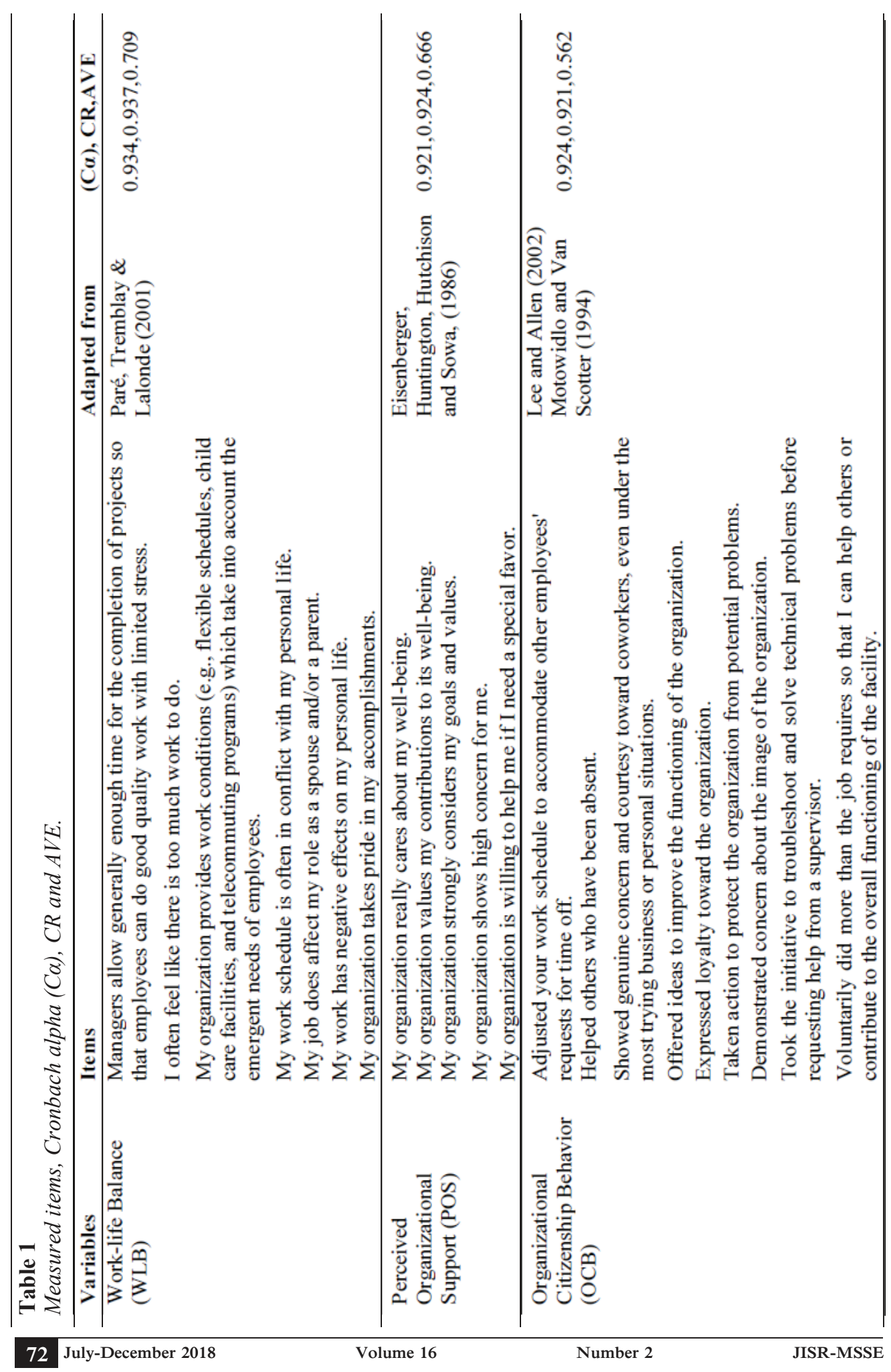




\section{Statistical Methodology:}

A measurement model is a part of an SEM model (Structure Equation Modelling) which specifies the relations between observed variables and latent variables. Confirmatory factor analysis is often used to test the measurement model. Measurement model reflects observed and latent variable relationship that is tested through confirmatory factor analysis technique in SEM.

\section{Confirmatory Factor Analysis (CFA)}

The researcher adopted the confirmatory factor analysis (CFA) technique and path analysis, structural equation modeling (SEM) to analyze data and administer the relationship between studied variables. The following section illustrates the results for confirmatory factor analysis developed for each construct. The CFA technique helped the researcher to test the hypothesis for every stated factor. The method also endeavors test a larger quantifiable data and is helpful in undertaking social sciences and behavioral studies.

Figure 1 Measurement Model for Pooled Construct.

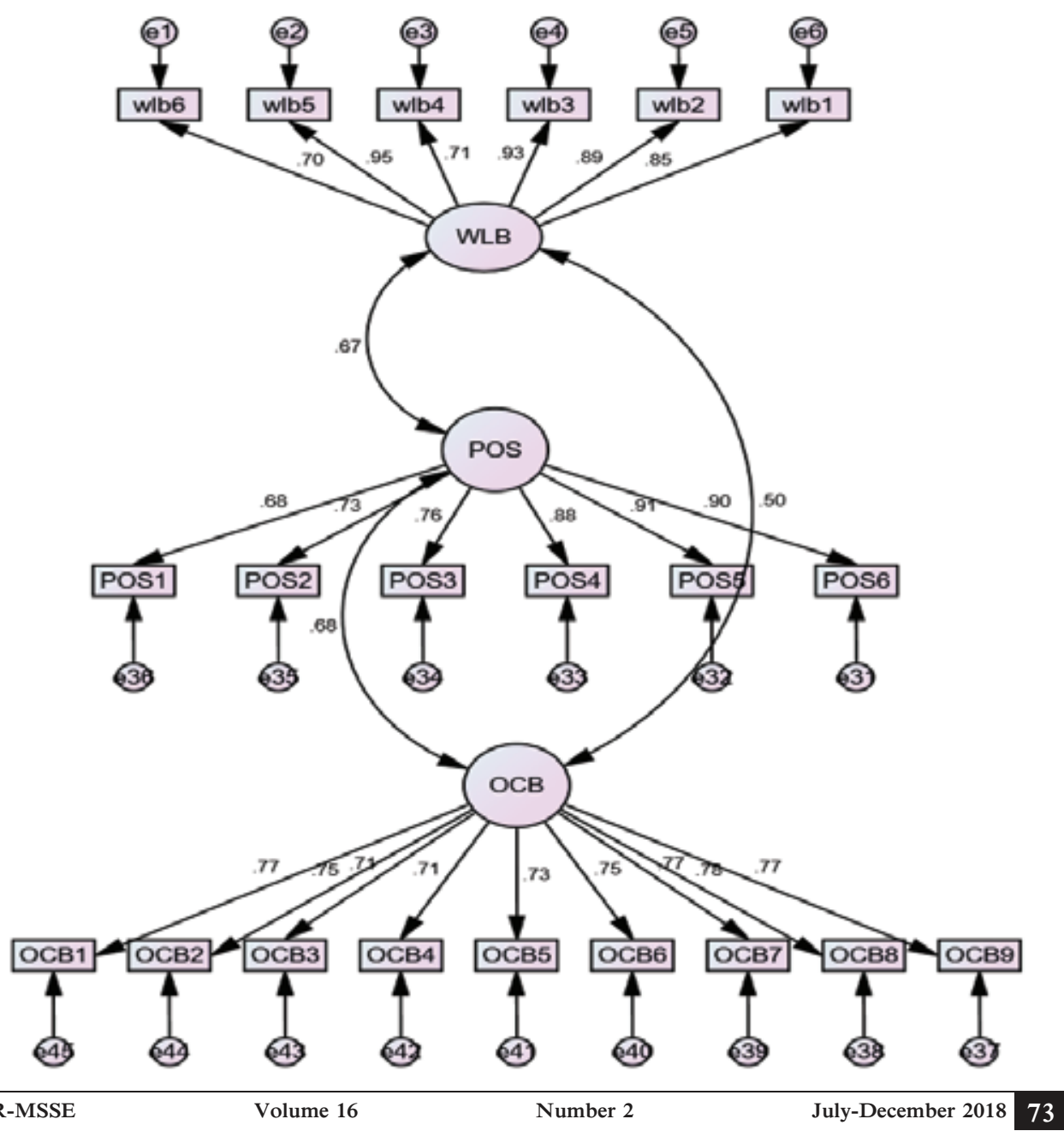




\section{Measurement Model for Pooled Construct}

The pooled confirmatory factor analysis has been executed to analyze the fitness of the measurement model. Following tables depicts the overall fitness of the model:

The fitness measures illustrate $\chi 2$ / df ratio 2.152 which is less than 3 and good for use. The researcher administered the model fit through the goodness of fit index (GFI), adjusted goodness of fit index (AGFI), comparative fit index (CFI) and root mean square error of approximation (RMSEA) for measuring model fit. The values for model fit measure enumerate as follows GFI (0.920), AGFI (0.901), CFI (0.967), TLI (0.963), NFI (0.947) and RMSEA (0.053). All the values show good fit since all the values are close to 1 , Bentler, (1992) Schumacker \& Lomax, (2004).

Table 2

Fitness of the Model.

\begin{tabular}{lllllllll}
\hline Chi- Square & $\chi 2 /$ df Ratio & p-Value & GFI & AGFI & CFI & TLI & NFI & RMSEA \\
\hline 467.289 & 2.152 & 0.000 & 0.920 & 0.901 & 0.967 & 0.963 & 0.947 & 0.053 \\
\hline
\end{tabular}

Note: $* * p<0.01, * p<0.05$.

Construct Validity:

CSince all the fitness indices are showing that the minimum acceptance level has been achieved we can say measurement model fulfill the requirements of construct validity.

\section{Discriminant Validity:}

As stated by Fornell \& Larcker, (1981) that the maximum shared variance (MSV) should be less than average variance extracted (AVE) for discriminant validity of the constructs in the measurement model. In this study the values of MSV are: WLB <--> POS $=0.443$, $\mathrm{WLB}<-->\mathrm{OCB}=0.253$ and $\mathrm{POS}<-->\mathrm{OCB}=0.465$. As all values of MSV are less than AVE values which shows an acceptable level of discriminant validity for all constructs in the measurement model of the study.

Table 3

Summary of the factor Analysis and model fit.

\begin{tabular}{llll}
\hline & & & Estimate \\
\hline wlb6 & $<---$ & F1 & .700 \\
wlb5 & $<---$ & F1 & .950 \\
wlb4 & $<---$ & F1 & .711 \\
wlb3 & $<---$ & F1 & .926 \\
wlb2 & $<---$ & F1 & .886 \\
wlb1 & $<---$ & F1 & .847 \\
POS6 & $<---$ & F5 & .905 \\
POS5 & $<---$ & F5 & .909 \\
POS4 & $<---$ & F5 & .881 \\
POS3 & $<---$ & F5 & .764 \\
POS2 & $<---$ & F5 & .727 \\
\hline
\end{tabular}

74 July-December 2018

Volume 16

Number 2

JISR-MSSE 


\begin{tabular}{llll}
\hline POS1 & $<--$ & F5 & .682 \\
OCB9 & $<---$ & F6 & .773 \\
OCB8 & $<--$ & F6 & .776 \\
OCB7 & $<--$ & F6 & .767 \\
OCB6 & $<---$ & F6 & .752 \\
OCB5 & $<--$ & F6 & .728 \\
OCB4 & $<---$ & F6 & .715 \\
OCB3 & $<---$ & F6 & .714 \\
OCB2 & $<---$ & F6 & .754 \\
OCB1 & $<---$ & F6 & .769 \\
\hline
\end{tabular}

Figure 2 Tested Research Model.

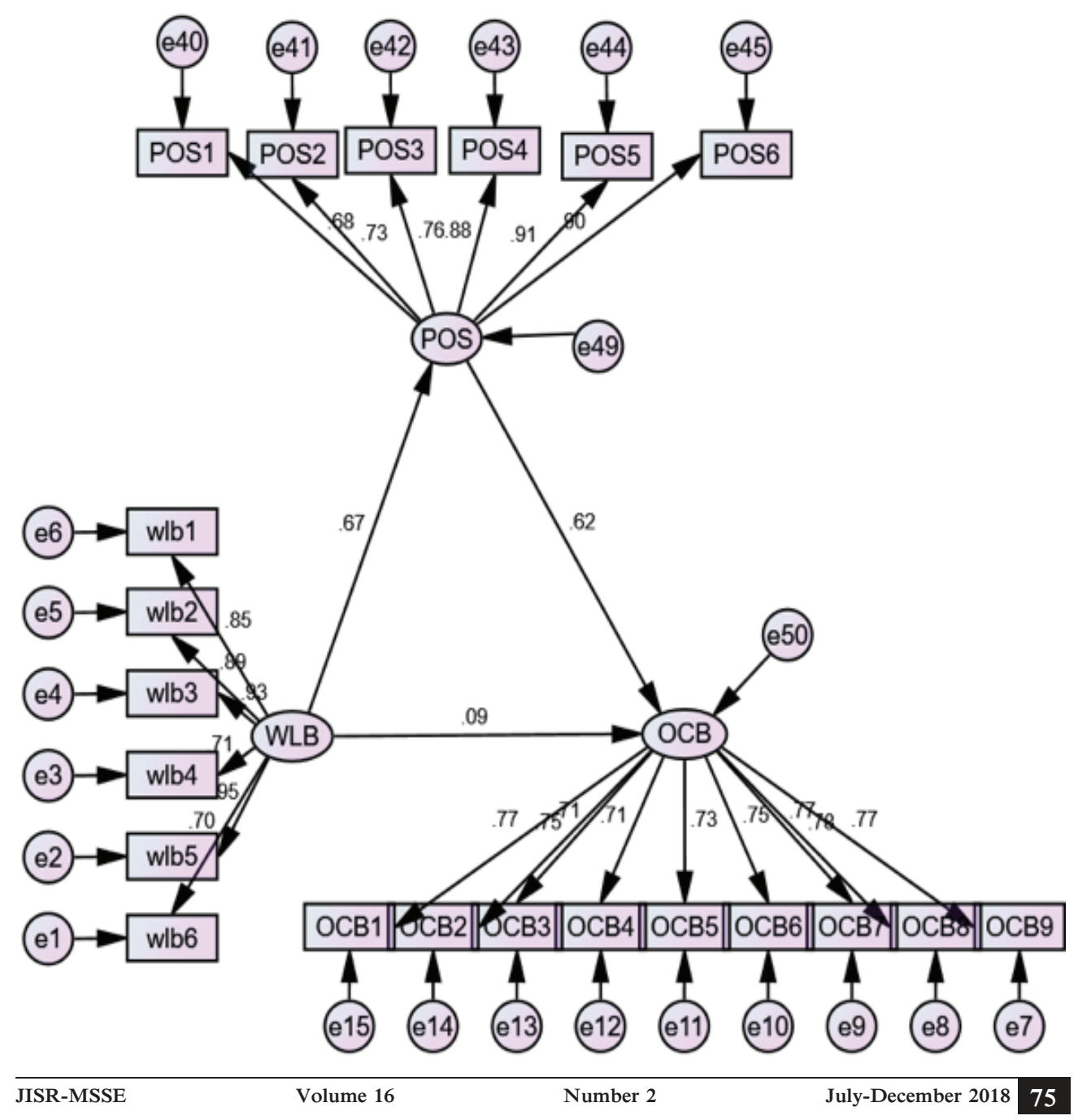


Table 4

Fitness of the Model.

\begin{tabular}{lllllllll}
\hline Chi- Square & $\chi 2 /$ df Ratio & p-Value & GFI & AGFI & CFI & TLI & NFI & RMSEA \\
\hline 467.289 & 2.152 & 0.000 & 0.920 & 0.901 & 0.967 & 0.963 & 0.947 & 0.053 \\
\hline
\end{tabular}

The fitness measures illustrate $\chi 2$ / df Ratio 2.512 which is less than 3 and good for use. The researcher administered the model fit through the goodness of fit index (GFI), adjusted goodness of fit index (AGFI), comparative fit index (CFI) and root mean square error of approximation (RMSEA) for measuring model fit. The values for model fit measure enumerate as follows GFI (0.920), AGFI (0.901), CFI (0.967), TLI (0.963), NFI (0.947) and RMSEA (0.053). All the values show good fit since all the values are close to 1, Zakuan, Yusof, Laosirihongthong, and Shaharoun, (2010), Singh-Manoux, Clarke and Marmot, (2002), Sacker, Bartley, Firth and Fitzpatrick, (2001), Bentler, (1992) Schumacker and Lomax, (2004).

Table 5

Results of Path Analysis - SEM.

\begin{tabular}{|c|c|c|c|c|c|c|c|}
\hline & & & Estimate & S.E. & C.R. & $\mathrm{P}$ & Results \\
\hline POS & $<--$ & WLB & 0.693 & .058 & 12.047 & $* * *$ & H1 Accepted \\
\hline OCB & $<--$ & WLB & 0.095 & .053 & 1.771 & .076 & H2 Rejected \\
\hline OCB & $<--$ & POS & 0.648 & .064 & 10.161 & $* * *$ & H3 Accepted \\
\hline
\end{tabular}

Table 6

Mediation based on Indirect Effect.

\begin{tabular}{|c|c|c|c|c|c|c|}
\hline \multirow{2}{*}{ Relationships } & \multirow{2}{*}{ Standardized $\beta$} & \multirow{2}{*}{$\mathrm{P}$} & \multicolumn{2}{|c|}{$\mathrm{BCCI}$} & \multirow{2}{*}{$\begin{array}{l}\text { Type of } \\
\text { Mediation }\end{array}$} & \multirow{2}{*}{ Results } \\
\hline & & & Lower & Upper & & \\
\hline WLB --->POS---->OCB & 0.4154 & $* * *$ & 0.333 & 0.586 & Full & H4 Accepted \\
\hline
\end{tabular}

Note: $\mathrm{ns}=$ not significant $, *=\mathrm{p}<0.05, * *=\mathrm{p}<0.01, * * *=\mathrm{p}<0.001$.

\section{WLB and Perceived Organizational Support H1:}

WLB shows direct significant effect on POS coefficient value, $(\beta=0.693)$ at $(\mathrm{p}=0.000<$ 0.05). The finding supports hypothesis $\mathrm{H} 1$, hence, the stated hypothesis can be accepted and the findings of the study are also in accord with the statement of Muse et. al., (2008) as they stated results of different researches validate that provision of WLB benefits are actually deliberated by workers, increases the insight of organizational support, organizational affective commitment (OAC) and reciprocation in the terms of improved role, better task and linked performance.

\section{Work-life Balance and Organizational Citizenship Behavior H2:}

The above table for path analysis depicts WLB-OCB regression statistics with insignificant coefficient value $(\beta=0.095)$ at $(\mathrm{p}=0.076>0.05)$ entail work-life balance practices have no direct effect on organizational citizenship behavior. The findings of the study are in accord with the study results of Durahman (2016) which was conducted in PT. Buma Apparel Industry Indonesia the results of study depict no significant association between work-life 
balance and employee's organization citizenship behavior while employees were unable to balance their work and family time whereas Prasetio (2016) study conducted, on BRI employees of Bandung Regional Office and Poohongthong, C., Surat, P., and Sutipan, P. (2014) study conducted on teachers in Northern Thailand, proposed a positive and significant association between work-life balance and Organization Citizenship Behavior.

\section{Perceived Organizational Support and OCB H3:}

The above table for path analysis depicts POS - OCB regression statistics with significant coefficient value $(\beta=0.648)$ at $(p=0.000<0.05)$ reflects the positive citizenship behavior on employee entails for the positive perceived support from the company in banking and telecommunication sector. The stated hypothesis, hence, can be accepted and the findings of this study also in accord with the study of Eisenberger et. al., (1990), where they examined the relationship among POS and OCB and revealed an important and positive relationship among those variables.

Moreover; workers feel themselves fundamentally motivated when the POS supports for WLB, Eaton, S.C., (2003) and work beyond their specified duties voluntarily. Researchers exploring the impact of owner supports for employees other than work-life have guessed that work-family initiative can improve employee's opinions of organizational support, Grover and Grooker, (1995), and Kossek, (1989).

\section{Mediation between Work-life Balance and Organizational Citizenship Behavior H4:}

The above table for indirect effect depicts the role of mediator between work-life balance and organizational citizenship behavior where mediator is perceived organizational support shows full mediation between WLB and OCB as WLB has shown significant indirect effect on OCB through POS (standardized $\beta=0.4154, \mathrm{p}<0.05$, Lower Bias-Corrected Confidence Interval $(\mathrm{BCCI})=0.333$, Upper BCCI $=0.586)$. On the contrary, WLB shows direct insignificant effect on OCB as coefficient value $(\beta=0.095)$ at $(\mathrm{p}=0.076<0.05)$. The finding supports hypothesis $\mathrm{H} 4$, hence, the stated hypothesis can be accepted. It is proposed by Hochwarter, Treadway, \& Ferris (2006), that perceived organizational support is a crucial element which influences organizational outcomes.

The findings confirm the crucial role of POS mediating the relationship between OCB and work-life balance initiatives and it also guides the WLB practitioners that providing work-life balance option are not enough to get desirable results but the fairness and availability of such option across the organizations are mandatory to achieve OCB. Moreover, Muhammed (2014), stated that it is assumed that the workers of the organizations will understand the offer of valuable work-life assistance by the organization as a care provided by the organizations to their life other than work and on the basis of different scientific proofs demonstrating the association between POS and OCB.

\section{DISCUSSION, CONCLUSION \& IMPLICATIONS FOR FUTURE RESEARCH}

\section{Discussion}

The present study was conducted to explore the effect of work-life balance on organizational citizenship behavior and to identify the mediating role of perceived organizational support in

\begin{tabular}{lll}
\hline JISR-MSSE & Volume 16 & Number 2
\end{tabular}


establishing the relationship between WLB and OCB. In this study, all the said variables are extracted and examined through hypothesis developed from the literature review.

The finding of the study suggest that the hypothesis $\mathrm{H} 1$ and H3 are supported and show consistency with previous studies of Muse et. al., (2008) and Eisenberger et. al., (1990), respectively. Moreover finding of the study depicts that hypothesis H3 is not supported as there is no significant direct relationship between WLB and OCB in the employees of service sector (banking and telecommunication) in Pakistan, such finding is inconsistent with the findings of previous different studies (e.g Prasetio (2016) and Poohongthong, C., Surat, P., and Sutipan, P. (2014)) and only results of the study conducted by Durahman (2016) are in accord while testing the direct association between WLB and OCB. As this is the first attempt to test the WLB impact on employees' OCB in banking and telecommunication sector of Pakistan and its finding acutely explains that there are gaps which are remaining to be bridged between policies, practices and their implementation.

The WLB initiatives need not only be restricted to flexible working options but the focus should be in developing an open work-life balance plan in which employees contribute their suggestions and design their own plan according to their individual needs. The finding of results further shows that hypothesis $\mathrm{H} 4$ is supported and confirm the crucial and mediating role of POS and it guides the WLB practitioners that providing work-life balance options are not enough to get desirable results but the fairness and availability of such option across the organization are mandatory to achieve OCB.

\section{Conclusion}

This study extends the contribution in a body of knowledge on Human Resource Management and Organizational Behavior, by investigating the associations of work-life balance and organizational citizenship behavior with the help of other variables in order to enhance the productivity and performance of organizations in Pakistan. Current study grounded on the sample of employees working in service sectors specifically banks and telecom companies in Pakistan where findings reveal that Work-Life balance practices positively contribute in the development of employee's organizational citizenship behavior if such policies are fair, well-communicated and accessible across the organization.

In this study, POS fully mediated the association between work-life balance practices and organizational citizenship behavior such results proposed the importance of employee's perception of organizational support generated by organizations work-life balance initiatives. This study determines that the challenges of globalization and increasing workforce diversity demands the balance in employees work and family life. As, Bloom et. al. (2013), stated that the features of person's work environment can directly impact the productivity of worker and organization moreover organizations that are keen to support work-life balance reap greater employee performance. So it is evident that employees generally not only seek the monetary rewards of their performance and productivity at work but they also demand organizations care for supportive work environment too. Now in the corporate world, every gesture of employee care by organizations is being noticed and returned in terms of extra efforts put at work by employees. 
Organizations in Pakistan need to introduce work-life balance initiatives carefully at workplace if they want to anticipate the challenges of productivity, performance, and competitiveness. Lambert, (2000) explored the perceived utility of WLB programs positively related to enhanced involvement in OCB. As work-life balance initiatives lead organization citizenship behavior among employees that is the key of organization's survival and sustainability in this era of globalization as this research supports the association between work-life balance practices and OCB mediated by POS.

\section{Implications for Future Research}

The variables used in the study have depicted great significance in progress of OCB but still, several other variables which can play a crucial role to further strengthen the study are not included and need to be considered in future research of OCB.

This study has shown the consistency with literature but there is a need to conduct a longitudinal study for detail examination and to comprehend the association among variables, Bollen (1989). Future studies in the similar domain if confirms the finding of this study then WLB practices can be used as mandatory part of the organization's strategies to engage employees in OCB and to overcome global challenges. The findings of this study will help the managers to understand and implement the importance of WLB initiatives at organizations keeping in view the role of social exchanges in order to achieve organizational citizenship behavior for performance and productivity.

Research results may serve as guidelines to the management in designing policies that may contribute towards the development of OCB within their organizations. In the telecom sector, WLB initiatives need to address the issues of flexible timings and teleworking, as the work in the telecom sector needs to be carried out 24/7. Whereas particularly to banks, the role of supervisors in the implementation of WLB initiatives for their subordinates need to be redefined by the policymakers, since the policies are there but the lack of communication and accessibility are highly dependent on managers' discretion, influencing the perception of fairness amongst employees.

The practical implications, in general, is to give an insight to the managers of both sectors about expectations of employees at work which will help them to introduce and improve work-life balance practices that can engage employees in organizational citizenship behavior.

\section{Limitations}

The limitations encountered in this study arises in the research sample taken in this study, which is primarily from the service sector and restricts the application of this research to others sectors and different businesses. So generalization of this research finding to different sectors may not be appropriate.

One more limitation to this study refers to the self-reported measures which are subjected to common method bias and do report un-necessary increase in relationships as established by Podsakoff and Organ (1986). Though extra care has taken in this study by using both positive and negative statements to reduce inflation of relationships up to some extent because in Pakistan the cultural aspect of collectivism hinders the freedom of acceptance and rejection of

\begin{tabular}{llll}
\hline JISR-MSSE & Volume 16 & Number 2 & July-December 2018 \\
\hline
\end{tabular}


behaviors socially, but for future research there is a need to use different sources for data collection to eliminate this issue.

\section{REFERENCES}

Aryasri, A. Ramachandra, and S. Suman Babu. (2007). "Work-Life Balance - A Holistic Approach."Siddhant-A Journal of Decision Making 7.1. 1-11.

Bakeman, R., and Gottman, J. M. (1986). Observing behavior: An introduction to sequential analysis. Cambridge: Cambridge University.

Baral, R., and Bhargava, S. (2010). Work-family enrichment as a mediator between organizational interventions for work-life balance and job outcomes. Journal of Managerial Psychology, 25(3), 274-300.

Baran, B. E., Shanock, L. R., \& Miller, L. R. (2012). Advancing Organizational Support Theory into the Twenty-First Century World of Work. Journal of Business and Psychology 27, 123-147.

Beauregard, T. A., \& Henry, L. C. (2009). Making the link between work-life balance practices and organizational performance. Human resource management review, 19(1), 9-22.

Bentler, P. M. (1992). On the fit of models to covariance and methodology to the Bulletin. Psychological Bulletin, 112(3), 400.

Bloom, Nicholas, Mark Schankerman, and John Van Reenen. (2013). "Identifying technology spillovers and product market rivalry." Econometrica 81.4 1347-1393.

Bolino, M. C., and Turnley, W. H. (2005). The personal costs of citizenship behavior: the relationship between individual initiative and role overload, job stress, and work-family conflict. Journal of Applied Psychology, 90(4), 740.

Bollen, Kenneth A. (1989). "A new incremental fit index for general structural equation models." Sociological Methods and Research 17.3 303-316.

Butts, M. M., Casper, W. J., \& Yang, T. S. (2013). How important are work-family support policies? A meta-analytic investigation of their effects on employee outcomes. Journal of Applied Psychology, 98(1), 1-25.

Chen, Z., Eisenberger, R., Johnson, K. M., Sucharski, I. L., \& Aselage, J. (2009). Perceived organizational support and extra-role performance: which leads to which?. The Journal of social psychology, 149(1), 119-124.

Cho, J., and Treadway, D. C. (2010). Organizational identification and perceived organizational support as mediators of the procedural justice-citizenship behavior relationship: A cross-cultural constructive replication. European Journal of Work and Organizational Psychology, 20(5), 631-653.

Cichorzewska, M., \& Rakowska, A. (2017). Organizational Citizenship Behavior of Polish and Ukrainian Civil Servants-A Comparative Study. In Management Challenges in a Network Economy: Proceedings of the MakeLearn and TIIM International Conference 2017 (pp. 393-394). ToKnowPress.

Crooker, K. J., Smith, F. L., \& Tabak, F. (2002). Creating work-life balance: A model of pluralism across life domains. Human Resource Development Review, 1(4), 387-419.

Durahman, A. (2016). Analisis Tingkat Work-life Balance dan Penilaian Kinerja terhadap Motivasi Kerja dan Organizational Citizenship Behavior Karyawan PT. Buma Apparel Industry di Subang. Tesis. (Tidak Diterbitkan). Universitas Pendidikan Indonesia: Bandung. 
Eisenberg, N., and Fabes, R. A. (1990). Empathy: Conceptualization, measurement, and relation to prosocial behavior. Motivation and Emotion, 14(2), 131-149.

Eisenberger, R., and Stinglhamber, F. (2011). Perceived organizational support: Fostering enthusiastic and productive employees. American Psychological Association.

Eisenberger, R., Armeli, S., Rexwinkel, B., Lynch, P. D., and Rhoades, L., (2001). Reciprocation of perceived organizational support. Journal of Applied Psychology, 86, 42-51. [22]

Eisenberger, R., Cotterell, N., and Marvel, J. (1987). Reciprocation ideology. Journal of Personality and Social Psychology, 53(4), 743.

Eisenberger, R., Curnmings, J., Armeli, S., and Lynch, P., (1997). Perceived organizational support, discretionary treatment, and job satisfaction. Journal of Applied Psychology, 82, 812- 820. [23]

Eisenberger, R., Fasolo, P., and Davis-LaMastro, V . (1990). Perceived organizational support and employee diligence, commitment, and innovation. Journal of Applied Psychology, $75(1), 51$.

Eisenberger, R., Huntington, R., Hutchison, S. and Sowa, D. (1986). "Perceived organizational support” Journal of Applied Psychology, Vol. 71, No. 3, pp. 500-507

Eisenberger, R., Stinglhamber, F., Vandenberghe, C., Sucharski, I., and Rhoades, L. (2002). Perceived supervisor support: Contributions to perceived organizational support and employee retention. Journal of Applied Psychology, 87, 565-573.

Eisenberger, Robert, et al. (2001). "Reciprocation of perceived organizational support." Journal of Applied Psychology 86.142.

Erdogan, B. and Enders, J.(2007), Support from the top: Supervisors' perceived organizational support as a moderator of leader-member exchange to satisfaction and performance relationships. Journal of Applied Psychology, 92(2): 321-330.

Fornell, C., \& Larcker, D. F. (1981). Structural equation models with unobservable variables and measurement error: Algebra and statistics. Journal of Marketing Research, 382-388.

Garg, P., \& Rastogi, R. (2006). New model of job design: motivating employees' performance. Journal of Management Development, 25(6), 572-587.

Grover, S. L., and Crooker, K. J. (1995). Who appreciates family-responsive human resource policies: The impact of family-friendly policies on the organizational attachment of/ parents and non-parents. Personnel Psychology, 48(2), 271-288

Guest, D. E. (2002). Perspectives on the study of work-life balance. Social Science Information, 41(2), 255-279.

Hair, J. F. Jr., Black, W. C., Babin, B. J., Anderson, R. E., and Tatham, R. L. (2006). Multivariate Data Analysis (6th ed.). Upper Saddle River, NJ: Prentice-Hall International

Harrell-Cook, G., Levitt, K., \& Grimm, J. (2017). From Engagement to Commitment: A New Perspective on the Employee Attitude-Firm Performance Relationship. International Leadership Journal, 9(1).

Hochwarter, W. A., Witt, L. A., Treadway, D. C., \& Ferris, G. R. (2006). The interaction of social skill and organizational support on job performance. Journal of Applied Psychology, 91(2), 482.

Hughes, J., and Bozionelos, N. (2007). Work-life balance as source of job dissatisfaction and withdrawal attitudes: An exploratory study on the views of male workers. Personnel Review, 36(1), 145-154. 
Jahanian, A., Nawaz, N., Yamin, R., \& Nawaz, M. A. (2012). Human resource management and productivity: a comparative study among banks in Bahawalpur division. Eur. J. Bus. Manage, 4(8), 253.

Kamil, N. M., Sulaimam, M., Selladurai, S., \& Khalid, N. (2015). The impact of spirituality and social responsibility on organizational citizenship behaviour from the Islamic perspective: Empirical investigation of Malaysian businesses. Jurnal Komunikasi, Malaysian Journal of Communication, 31(1).

Khan, M. A., Safwan, N., \& Ahmad, A. (2011). Modeling link between internal service quality in human resources management and employees retention: A case of Pakistani privatized and public sector banks. African Journal of Business Management, 5(3), 949-959.

Khilji, S. E. (2003). To Adapt or Not to Adapt' Exploring the Role of National Culture in HRM-A Study of Pakistan. International Journal of Cross Cultural Management, 3(1), 109-132.

Konrad, A., and Mangel, R. (2000). The impact of work-life programs on firm productivity. Strategic Management Journal, 21(12), 1225-1237.

Krishnan J., \& Mary, V.S., (2012). Perceived organizational support an overview on its antecedents and consequences. International Journal of Multidisciplinary Research, 2(4), 1-13.

Kuusisto, L. (2017). The meaning of organizational citizenship behavior in wellbeing at work.

Lambert, S. (2000). Added benefits: the link between work-life benefits an organizational citizenship behavior. Academy of Management Journal 43 (5): 801-815

Lee, K., and Allen, N. J. (2002). Organizational citizenship behavior and workplace deviance: the role of affect and cognitions. Journal of applied psychology, 87(1), 131.

Leedy, P. and Ormrod, J. (2001) Practical Research: Planning and Design. $7^{\text {th }}$ Edition, Merrill Prentice Hall and SAGE Publications, Upper Saddle River, NJ and Thousand Oaks, CA

MacKenzie, S.B., Podsakoff, P.M. and Ahearne, M. (1998). Some possible antecedents and consequences of in-role and extra-role salesperson performance, Journal of Marketing, $62(3), 69-86$.

McAllister, D. J., Kamdar, D., Morrison, E. W., and Turban, D. B. (2007). Disentangling role perceptions: how perceived role breadth, discretion, instrumentality, and efficacy relate to helping and taking charge. Journal of Applied Psychology, 92(5), 1200.

Miech, R. A., Eaton, W., and Liang, K. Y. (2003). Occupational stratification over the life course a comparison of occupational trajectories across race and gender during the 1980s and 1990s. Work and Occupations, 30(4), 440-473.

Moideenkutty, U., Blau, G., Kumar, R., and Nalakath, A. (2005). Relationship of organization citizenship behavior and objective productivity to managerial evaluations of performance in India. International Journal of Commerce and Management, 15(3/4), 221-229.

Moorman, R. H. (1991). Relationship between organizational justice and organizational citizenship behaviors: Do fairness perceptions influence employee citizenship? Journal of applied psychology, 76(6), 845.

Moorman, R. H., Blakely, G. L., and Niehoff, B. P. (1998). Does perceived organizational support mediate the relationship between procedural justice and organizational citizenship behavior? Academy of Management Journal, 41(3), 351-357.

Moorman, R. H., Niehoff, B. P., and Organ, D. W. (1993). Treating employees fairly and organizational citizenship behavior: Sorting the effects of job satisfaction, organizational commitment, and procedural justice. Employee responsibilities and rights journal, 6(3), 209-225.

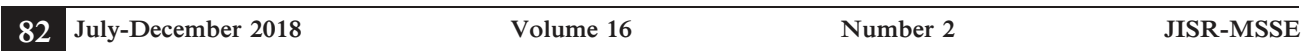


Motowidlo, S. J. (2003). Job performance. Handbook of psychology.

Motowidlo, S. J., and Van Scotter, J. R. (1994). Evidence that task performance should be distinguished from contextual performance. Journal of Applied Psychology, 79(4), 475.

Muhammad, A. H. (2014). Perceived organizational support and organizational citizenship behavior: the case of Kuwait. International Journal of Business Administration, 5(3), 59.

Muse, L., Harris, S. G., Giles, W. F., and Field, H. S. (2008). Work-life benefits and positive organizational behavior: is there a connection? Journal of Organizational Behavior, 29(2), 171-192

Muse, L. A., \& Pichler, S. (2011). A comparison of types of support for lower-skill workers: Evidence for the importance of family supportive supervisors. Journal of Vocational Behavior, 79(3), 653-666.

O’Driscoll, M. P., Poelmans, S., Spector, P. E., Kalliath, T., Allen, T. D., Cooper, C. L., and Sanchez, J. I. (2003). Family Responsive Interventions, Perceived Organizational and Supervisor Support, Work-Family Conflict Act, and Psychological Strain. International Journal of Stress Management, 10(4), 326-344.

Oktariani, D., Hubeis, A.V. S., \& Sukandar, D. (2017). “Kepuasan Kerja Generasi X Dan Y Terhadap Komiten Kerja

Di Bank Mandiri Palembang”, Jurnal Aplikasi Bisnis Dan Manajemen, Vol. III (1): 12-22.

Oludayo, O. A., Falola, H. O., Obianuju, A., \& Demilade, F. (2018). Work-Life Balance Initiative as a Predictor of Employees' Behavioural Outcomes. Academy of Strategic Management Journal.

Oparanma, A. O., \& Nwaeke, L. I. (2015). Impact of job rotation on organizational performance. British Journal of Economics, Management \& Trade, 7(3), 183-187.

Organ, D. W. (1988). Organizational citizenship behavior: The good soldier syndrome. Lexington Books/DC Heath and Com.

Osterman, P. (1995). Work/family programs and the employment relationship. Administrative science quarterly, 681-700.

Paré, G., Tremblay, M., and Lalonde, P. (2001). The role of organizational commitment and citizenship behaviors in understanding relations between human resources practices and turnover intentions of IT personnel. Cahier du GRe SI no, 1, 07.

Poohongthong, C., Surat, P., \& Sutipan, P. (2014). "A Study on the Relationships between Ethical Leadership, WorkLife Balance, Organizational Socialization, and Organizational Citizenship Behavior of Teachers in Northern Thailand", International Journal of Behavioral Science, Vol. IX (2): 17-28.

Prasetio, A. P. (2016). Pengaruh Work-life Balance Terhadap Oganizational Citizenship Behavior. Disertasi. (Tidak Dipublikasikan). Universitas Pendidikan Indonesia: Bandung

Qayum, A. (2011). HRM: Does It Matters, Pakistan today. [Online] Available fromhttp://www.pakistantoday.com.pk/2011/01/18/comment/editors-mail/hrm-does-itmatter

Robbins, S. P., Judge, T. A. (2017). Organizational Behavior. Upper Saddle River, NJ: Pearson Prentice Hall

Schumacker, R. E., and Lomax, R. G. (2004). A beginner's guide to structural equation modeling. Psychology Press.

Sekaran, U. (2002). Research methods for business. Willey and Sons, USA.

Sekaran, U. (2006). Metodologi Penelitian Untuk Bisnis.

Sheikh, M. A., Ashiq, A., Mehar, M. R., Hasan, A., \& Khalid, M. (2018). Impact of Work and Home Demands on Work Life Balance: Mediating Role of Work Family Conflicts.

\begin{tabular}{llll}
\hline JISR-MSSE & Volume 16 & Number 2 & July-December 2018 \\
\hline 83
\end{tabular}


Singh-Manoux, A., Clarke, P., and Marmot, M. (2002). Multiple measures of socio-economic position and psychosocial health: proximal and distal measures. International Journal of Epidemiology, 31(6), 1192-1199.

Tremablay, M., Rondeau, A. and Lemelin, M. (1998). Influence of Human Resource Practices on the Mobilization of Blue-Collar Workers (in French). Proceedings of Meetings of Association Internationale de Psychologie de Langue Françoise, 97-110.

Wayne, S. J., Shore, L. M., Bommer, W. H., and Tetrick, L. E. (2002). The role of fair treatment and rewards in perceptions of organizational support and leader-member exchange. Journal of Applied Psychology, 87(3), 590.

Williams, P., Pocock, B., \& Skinner, N. (2008). "Clawing back time": expansive working time and implications for work - life outcomes in Australian workers. Work, Employment and Society, 22(4), 737-748.

Yasbek, P. (2004). The business case for firm-level work-life balance policies: a review of the literature.

Zakuan, N. M., Yusof, S. M., Laosirihongthong, T., and Shaharoun, A. M. (2010). Proposed relationship of TQM and organizational performance using structured equation modelling. Total Quality Management, 21(2), 185-203.

Zare, H., Haghgooyan, Z., \& Karimi Asl, Z. (2014). Identification the components of quality of work life and measuring them in faculty members of Tehran University. Iranian Journal of Management Studies, 7(1), 41-66.

Zhong, L., Wayne, S. J., and Liden, R. C. (2016). Job engagement, perceived organizational support, high-performance human resource practices, and cultural value orientations: a cross-level investigation. J. Organ. Behav. 37, 823-844. DOI: 10.1002/job.2076. 